\title{
Apotex loses case based on the 'Festo' ruling
}

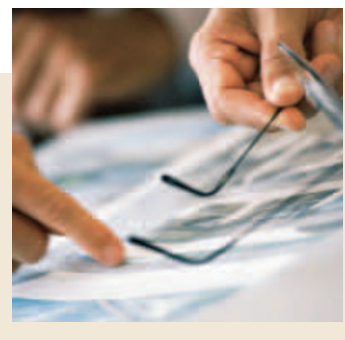

The Federal Circuit Court of Appeals has affirmed the New Jersey District Court's denial of a preliminary injunction sought by Apotex against Ranbaxy to prevent them from using one of Apotex's patented methods. The patent (US $5,847,118$ ) is directed to methods for making amorphous cefuroxime axetil, an antibiotic used to treat tonsillitis, sinusitis and skin infections. Apotex asserted its patent under the doctrine of equivalents, admitting that there was no literal infringement by Ranbaxy. In general, the doctrine of equivalents is an equitable concept used to prevent someone from gaining the benefit of the invention by making a minor change that avoids literal infringement; according to this doctrine, one can be held liable as an infringer even if one does not literally infringe a patent.

During the prosecution of Apotex's '118 patent, the sole independent claim was rejected as indefinite because the examiner questioned how the term 'high polarity' was bounded in the claim phrase 'highly polar organic solvent'. Apotex amended the claim by adding the limitation that "the highly polar organic solvent is selected from the group consisting of a sulfoxide, an amide and formic acid". Citing the Festo rule (see below), the Federal Circuit ruled that having made such an amendment, Apotex was presumed to have surrendered from the scope of the claim all equivalents that might have been encompassed by the phrase 'highly polar organic solvent', thereby limiting the claim's scope to the literally recited sulfoxides, amides and formic acid. The Federal Circuit then found that Apotex could not rebut the presumption of surrender of equivalents on the grounds that the equivalent would have been unforeseeable at the time of the amendment (one of three permissible rebuttals enumerated by the Supreme Court), finding specifically that acetic acid was readily known to be equivalent to formic acid at the time the amendment was made.

On 28 May 2002, the US Supreme Court vacated the earlier ruling of the 2000 US Court of Appeals for the Federal Circuit (Festo Corp. v Shoketsu Kinzoku Kogyo Kabushiki Co.), which had ruled that in the process of amending the claims of their patent, Festo Corp. had relinquished the protection afforded by the doctrine of equivalents. This applied to all equivalents, not just to those equivalent products that related to the amended claim, and not just to those amendments that were meant to narrow the claim to avoid prior art. The Supreme Court instructed that Federal Courts could presume that patentees abandon the right to protection under the doctrine of equivalents with respect to any elements that are contained in an amendment, but that patentees could rebut this presumption and claim equivalent protection in such cases if they can prove that the equivalent could not reasonably have been foreseen at the time of drafting the amendment.

Ranbaxy Pharmaceticals Inc. versus Apotex, Inc.: http://www.fedcir.gov/opinions/02-1429.doc Festo Corp. v Shoketsu Kinzoku Kogyo Kabushiki Co.:

http://www.usdoj.gov/osg/briefs/2001/3mer/1ami/2000-1543.mer.ami.pdf

Further elaboration September 2003: http://www.fedcir.gov/opinions/95-1066c.doc

\section{Patent write-offs are a write off}

At the end of 2003, the Internal Revenue Service (IRS) announced that it will disallow certain "improper deductions" on tax returns for charitable contributions of patents and other intellectual property. This means that companies are set to lose millions of dollars in tax write-offs from donating their patents to universities and non-profit groups. The main problems with the tax breaks were that the estimation of patent value was often inflated, and companies were often giving away only a partial interest in the patent even though the whole patent must be divested to qualify for a deduction. Commissioner Mark Everson declared that the IRS will penalize not only companies who take improper deductions, but also promoters and appraisers who assist with such arrangements. The new rules could make things difficult for lawyers whose corporate clients use patent donations to gain big tax write-offs. In addition, the IRS intends to look closely at two other patent enforcement issues. The first is the transfer of patents to offshore holding companies, which sometimes allows the patent holder to avoid capital gains tax should the patent actually become valuable. The second is whether companies who take research tax credits for new innovations that might result in a patent really qualify for the credit.

\section{Purdue appeals OxyContin patents}

Purdue Pharma LP's patents covering its blockbuster painkiller OxyContin are invalid, according to Judge Sidney Stein of the US District Court for the Southern District of New York. The Connecticut-based company sued drug maker Endo Pharmaceuticals Holdings, Inc. for patent infringement in 2000 after Endo filed an Abbreviated New Drug Application with the US FDA to sell generic OxyContin. Judge Stein found that although Endo had infringed three of Purdue's patents, the patents were unenforceable due to "inequitable conduct" by Purdue. Endo said that Purdue's many patents on OxyContin were invalid. Purdue told the patent office that OxyContin was unique because $90 \%$ of patients taking the medicine got pain relief by taking a very low dose (10-40 mg). During the course of the trial, OxyContin's inventor, Robert F. Kaiko, acknowledged that he had done no clinical studies and had no evidence to support this claim. Purdue admitted that Kaiko's 'discovery' was made solely in his head, but claimed that it was valid even though the company was unable to prove it to be true. Internal company documents from 1993 show that Purdue executives concluded that the claims that the company were making for OxyContin were not close to being proved and were "clearly Kaiko's vision". In his ruling, Judge Stein wrote that "Purdue made a deliberate decision to misrepresent to the US Patent Office a 'theoretical argument' and an 'expectation' as a precisely quantified 'result' or 'discovery'”. Purdue has filed an appeal to the Federal circuit; in cases in which district courts have made findings of inequitable conduct, the Court of Appeals for the Federal District has either reversed or vacated those rulings in more than $70 \%$ of the cases within the last year. Connecticut Attorney General Richard Blumenthal has launched an antitrust probe to determine whether Purdue Pharma prevented the development of less-costly generic alternatives. 